\title{
The impacts of geochemistry and agricultural activities on groundwater quality in the Soutpansberg fractured aquifers
}

\author{
J. O. Odiyo, R. Makungo \& T. G. Muhlarhi \\ Department of Hydrology and Water Resources, University of Venda, \\ South Africa
}

\begin{abstract}
A study has been made to investigate the impacts of geochemistry and agricultural activities on groundwater quality in the Soutpansberg Mountains and its neighbourhoods, South Africa. The agrochemicals, livestock wastes, decayed plants and geochemistry potentially pollute groundwater. The physical and chemical parameters were measured and analyzed in the field and laboratory, respectively. The $\mathrm{pH}$ and electrical conductivity were within the recommended guidelines. Turbidity exceeded the recommended guidelines in most of the boreholes. Calcium and magnesium exceeded the acceptable levels. Nitrate, chloride and sulphate were within acceptable levels except for boreholes in northern and the south-western side of the mountain. The high levels of the metals and non-metals are mainly from fertilizers, organic waste and waste sludge used to improve production and from livestock. The impacts of agricultural activities on groundwater quality varied from one farm to another. The geologic formations of the study area do not have significant impacts on groundwater quality.

Keywords: agricultural activities, fractured aquifers, geochemistry, groundwater quality, Soutpansberg.
\end{abstract}

\section{Introduction}

Groundwater chemistry depends on a number of factors, such as general geology, degree of chemical weathering of the various rock types, quality of recharge water and inputs from sources other than water-rock interaction [1]. 
Inputs from other sources may include effluents from agriculture, industrial and domestic activities. Groundwater chemistry in the fractured-bedrock aquifer is dependent on various hydrogeologic factors such as mineral composition, physical contact, residence time, and oxidation-reduction conditions; all factors that affect the solubility of bedrock minerals [2]. Naturally groundwater contains mineral ions which slowly dissolve from soil particles, sediments, and rocks as the water travels along mineral surfaces in the pores and fractures of the unsaturated zone and the aquifer [3]. These minerals impact on the groundwater quality.

Groundwater contamination decreases the amount of available groundwater, especially in the presence of fractures and macro-pores, which can rapidly distribute solutes over vast areas [4]. Fertilizers, pesticides and herbicides applied to crops reach underlying aquifers particularly if the aquifer is shallow and not protected by an overlying layer of low permeability material such as clay [5]. Discharge of effluent from intensive livestock units, leachate from manure stores and leaking slurry pits and slurry or manure spread on land as organic fertilizer can all be sources of groundwater pollution [6]. Thus, wastes from livestock commercial farms and decaying plant parts contribute to groundwater pollution particularly by increasing the nitrate levels. Run-off from all categories of agricultural activities also results in surface and groundwater pollution. Irrigation return flows carry salts, nutrients and pesticides [7]. The extent of nitrate contamination, and how quickly it occurs, depends both on soil type and on depth of the water source [8]. Nitrates can leach more easily in light sandy soils than in clay-based soils [9]. Elevated nitrate concentrations in groundwater are common around dairy and poultry operations, barnyards, and feedlots [10].

Some of the farmers in the study area use fertilizers containing magnesium and calcium. Calcium is a constituent of most fertilizers. For example a farm which is located at the knee of the mountain (south of the Soutpansberg) uses about $12.5 \mathrm{~kg} / \mathrm{ha} /$ year of calcium in an area of $1.1 \mathrm{ha}$. A farm located at the south-western side of the mountain experiences problems of scaling with their boilers, and this in turn damages the boilers. Calcium and magnesium are responsible for scaling of electrical appliances. Some of the farmers use fertilizers containing nitrates to improve their productivity. This in addition to nitrates from livestock wastes and decayed plant materials make nitrates a subject of investigation on groundwater quality in the Soutpansberg.

Minerals such as copper, iron, refractory flint, salt, sillimanite and coal among others are found within the Soutpansberg Mountains. It is important to investigate their presence and impact on groundwater in different sites as they may not be available everywhere. The mountain is endowed with economic minerals and only copper mineralization is considered to be sub-economic [11]. Salt $(\mathrm{NaCl})$ is produced in the Soutpansberg from brines pumped up from deep wells [11] and this motivated the investigation of chlorides problems linked to sodium. High concentrations of fluorides have been detected in groundwater in the leeward (northern) side of Soutpansberg at Siloam Village [12, 13]. It was therefore important to investigate whether this is a localized or a widespread problem within the Soutpansberg Mountains. The geology of the Soutpansberg is 
dominated by igneous, metarmorphic and sedimentary rocks (Fig. 1) and this provided the basis for investigating the presence of the minerals linked to geology. Magnesium naturally occurs in basic igneous rocks [14], volcanic rocks such as basalts [15], metamorphic rocks $[15,16]$ and sedimentary rocks $[15]$.

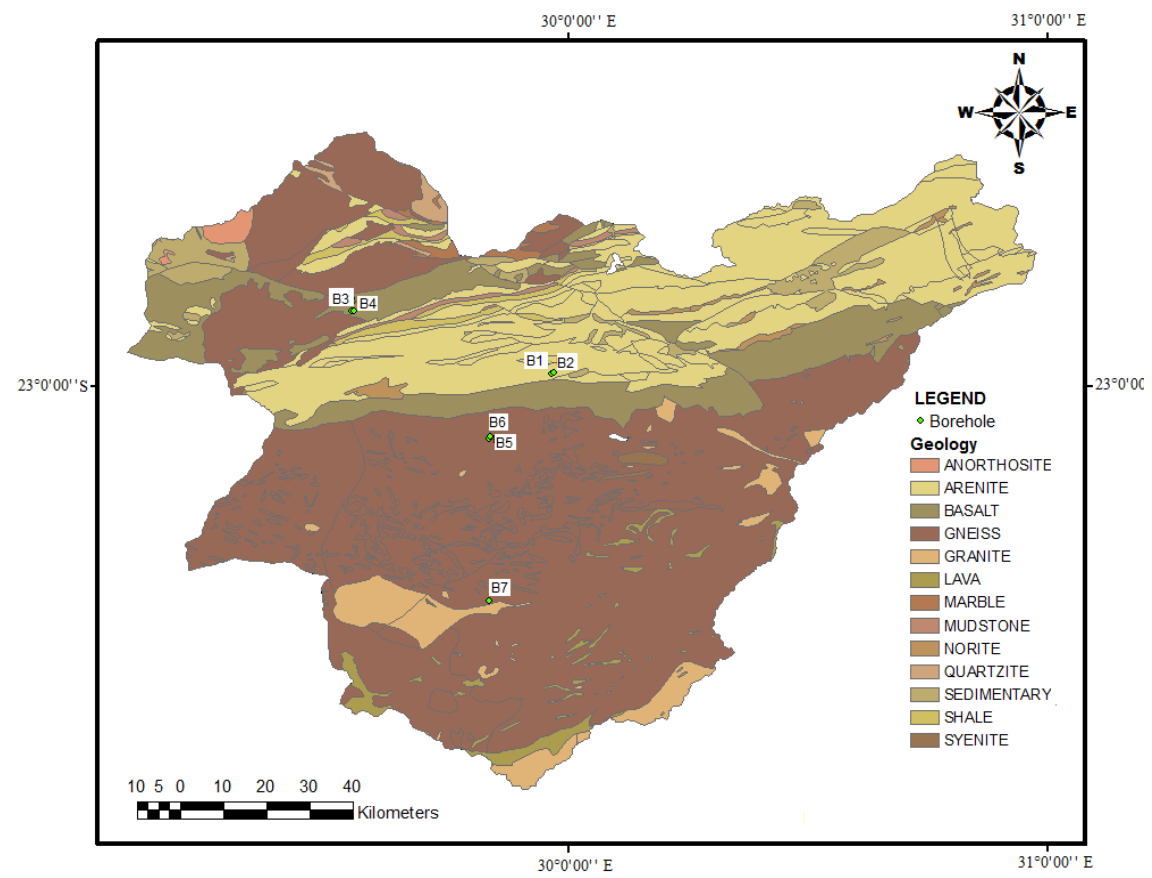

Figure 1: Geology of the study area.

The aim of this study is to investigate the impacts of minerals linked to the geology of the groundwater aquifers and the impact of commercial farming dominant in the Soutpansberg mountainous area. Thus the study looks at groundwater pollution in terms of the impacts the major sources of pollution surrounding the aquifers have the potential to cause. This contributes towards the recommendation of management strategies. Dealing with known sources of pollution makes it easy to plan monitoring activities and intervention measures. Major commercial farming using groundwater for irrigation of crops in which there is an intensive and extensive use of fertilizers, pesticides and herbicides; animal feeding and domestic purposes occur in the Soutpansberg area. Since the same groundwater is used for domestic purposes without treatment in the area of study, it is important to investigate its quality so that where necessary home based treatment can be recommended. 


\section{Study area}

The Soutpansberg Mountain is situated in Limpopo Province of South Africa. Soutpansberg is a prominent quartzite mountain range situated just north of the Tropic of Capricorn. The Soutpansberg area extends in an east-west direction for about $210 \mathrm{~km}$, with a width of up to $60 \mathrm{~km}$ and a surface area of $6800 \mathrm{~km}^{2}$ [11]. It extends from the town of Vivo in the west to Punda Maria in the Kruger National Park in the east. The study area is located within latitudes $22^{\circ} 47^{\prime} \mathrm{S}$ and $23^{\circ} 19^{\prime} \mathrm{S}$ and longitudes $29^{\circ} 29^{\prime} \mathrm{E}$ and $30^{\circ} 47^{\prime} \mathrm{E}$ (Fig. 2). The contour height shows the variation in altitude within part of the Soutpansberg which constitutes the study area.

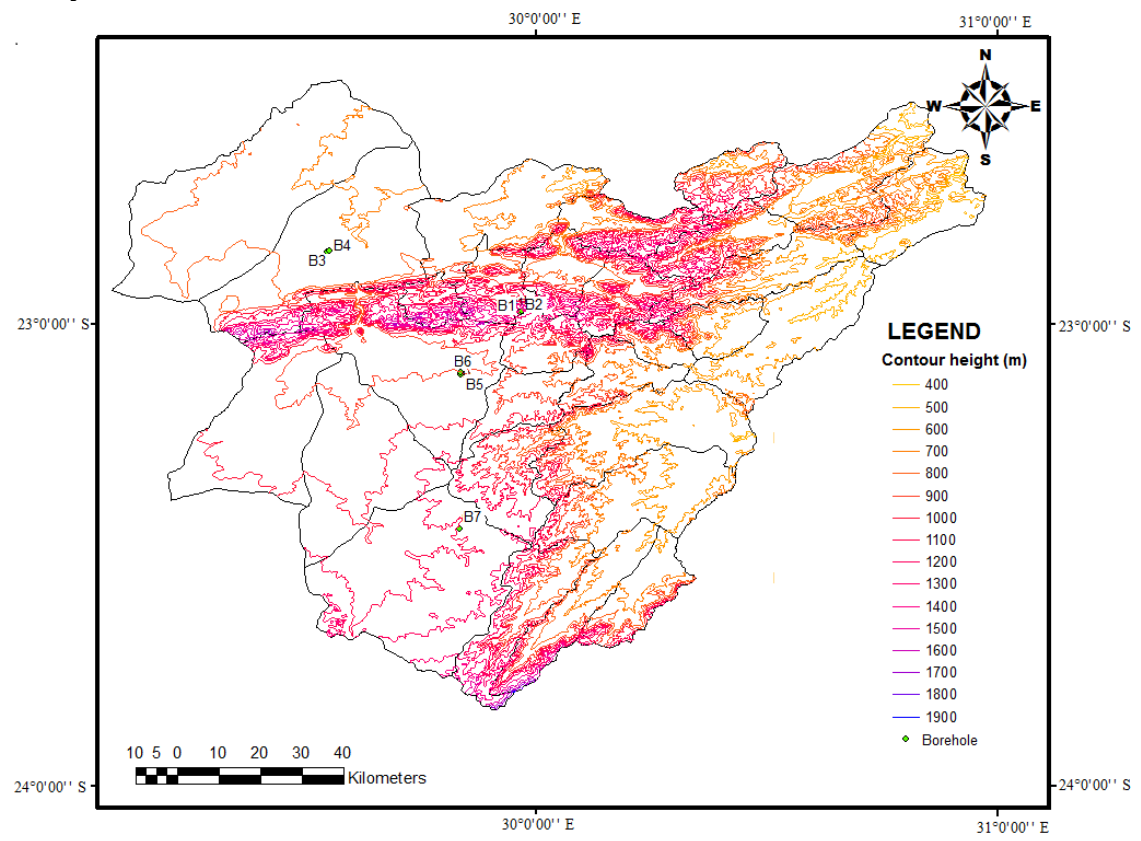

Figure 2: Study area and topography.

\section{Methodology}

Seven boreholes located in four commercial farms within the Soutpansberg mountains area were selected for the study. The farms were located on top, northern side, southern side and at the anklet of the mountain (Table 1). Two sets of water samples were taken from each of the farms in October and December 2008 for analyses. October represented a dry month as the rains were late and December represented a wet month. Water quality parameters that were measured include electrical conductivity (EC), $\mathrm{pH}$, turbidity and concentrations of specific metals and non-metals. $\mathrm{pH}$ and electrical conductivity were measured 
in the field using the multi 340i multimeter. The Orion AQ2010 AQUAFast II turbidity meter was used for field measurements of turbidity. The equipments were calibrated following the manufacturers' guidelines.

Table 1: Sampling sites.

\begin{tabular}{|c|c|c|c|}
\hline $\begin{array}{l}\text { Borehole number/ } \\
\text { sampling point }\end{array}$ & Location & Coordinates & Elevation \\
\hline Borehole no 1 (B1) & Top of the mountain farm & $\begin{array}{l}\text { S } 22^{\circ} 58^{\prime} 24.0^{\prime \prime} \\
\text { E 29॰57' } 53.4^{\prime \prime}\end{array}$ & $1317 \mathrm{~m}$ \\
\hline Borehole no 2 (B2) & Top of the mountain farm & $\begin{array}{l}\text { S } 22^{\circ} 58^{\prime} 16.5^{\prime}, \\
\text { E } 29^{\circ} 58^{\prime} 12.1^{\prime}\end{array}$ & $1347 \mathrm{~m}$ \\
\hline Borehole no 3 (B3) & $\begin{array}{l}\text { Northern side of the } \\
\text { mountain farm }\end{array}$ & 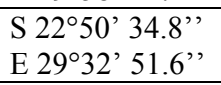 & $744 \mathrm{~m}$ \\
\hline Borehole no 4 (B4) & $\begin{array}{l}\text { Northern side of the } \\
\text { mountain farm }\end{array}$ & 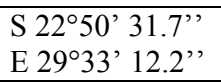 & $744 \mathrm{~m}$ \\
\hline Borehole no 5 (B5) & $\begin{array}{l}\text { Southern side of the } \\
\text { mountain farm }\end{array}$ & $\begin{array}{l}\text { S 2306' } 31.7^{\prime} \\
\text { E 2950' } 10.9\end{array}$ & $905 \mathrm{~m}$ \\
\hline Borehole no 6 (B6) & $\begin{array}{l}\text { Southern side of the } \\
\text { mountain }\end{array}$ & $\begin{array}{l}\text { S } 23^{\circ} 06^{\prime} 34.2^{\prime \prime} \\
\text { E 29॰50' } 13.9^{\prime \prime}\end{array}$ & $904 \mathrm{~m}$ \\
\hline Borehole no 7 (B7) & $\begin{array}{l}\text { At the anklet of the } \\
\text { mountain farm }\end{array}$ & $\begin{array}{l}\text { S 2303' } 15.8^{\prime \prime} \\
\text { E } 30^{\circ} 04^{\prime} 12.9^{\prime}\end{array}$ & $824 \mathrm{~m}$ \\
\hline
\end{tabular}

The metals (calcium, magnesium, copper, lead and iron) were analyzed using the AAnalyst 400 Atomic Absorption Spectrometry (AAS) supplied by Perkin Elmer located in USA. The non-metals (sulphate, chloride, fluoride, phosphate and nitrate) were analyzed using the Intelligent 850 Professional Ion Chromatography (IC) supplied by Metrohm.

\subsection{Preparation of calibration standards and analyses of non-metals and metals}

Sodium chloride $(\mathrm{NaCl})$, sodium fluoride $(\mathrm{NaF})$, sodium nitrate $\left(\mathrm{NaNO}_{3}\right)$, potassium sulphate $\left(\mathrm{K}_{2} \mathrm{SO}_{4}\right)$ and sodium phosphate $\left(\mathrm{Na}_{2} \mathrm{HPO} 4\right)$ were used to prepare calibration standards for chloride, fluoride, nitrate, sulphate and phosphate. The samples were filtered prior to analyses in order to remove sediments and other particulate matter. To limit the potential for microbial alteration, the samples were filtered through $0.45 \mu \mathrm{m}$ filters.

The pressure of the instrument (IC) was set at 5.69 Mpa and at a temperature of $30^{\circ} \mathrm{C}$. An eluent was prepared which consisted of $\mathrm{NaHCO}_{3}-1.0 \mathrm{mmol} / \mathrm{L}$ and $\mathrm{Na}_{2} \mathrm{CO}_{3}-3.2 \mathrm{mmol} / \mathrm{L}$. The calibration standards were then injected into the IC. The standards were analyzed to set the calibration curves, followed by analysis of distilled water before the analyses of the samples.

Calibration standards for metals were prepared from 1000 ppm stock solutions. Standards were prepared for manganese, cadmium, copper, zinc, iron and lead. The calibration standard concentrations for these metals were $0.5 \mathrm{ppm}$, $1 \mathrm{ppm}, 2 \mathrm{ppm}, 5 \mathrm{ppm}$ and $10 \mathrm{ppm}$. The calibration standards for magnesium and calcium were of $5 \mathrm{ppm}, 10 \mathrm{ppm}, 20 \mathrm{ppm}, 50 \mathrm{ppm}, 100 \mathrm{ppm}$ and $250 \mathrm{ppm}$ as 
groundwater is likely to have high concentrations of these elements. The calibration standards were run to set the calibration curves. The calibration curves readings were plotted as absorption against concentration.

The samples were analyzed by AAS. Each sample was introduced into a flame, the sample solution was then dispersed into a fine spray, and the particles vaporized into neutral atoms, ionic species and molecular species. The light produced by the hallow-cathode lamp emitted from excited atoms of the same element corresponding directly to the wavelength which is absorbed by the atomized sample was recorded. The results obtained were printed-out and recorded accordingly. For quality assurance purposes, each sample was analyzed in triplicates for both metals and non-metals.

\section{Results and discussion}

The turbidity in all the boreholes in the study area ranged from a minimum of 0.2 NTU to a maximum of 91 NTU (Table 2). The turbidity for most of the boreholes was higher during the dry month than the wet month because of the reduction in the water table as a result of agricultural and domestic abstractions. Pumping of the water at the bottom of the borehole disturbs the settled fine particles, which are thus abstracted with the water and hence increases the turbidity.

The $\mathrm{pH}$ values in all the boreholes in both the dry and the wet months (October and December 2008), respectively, (Table 2) were within acceptable DWAF [17] guidelines of 6.0 to 9.0 for human consumption. For agriculture the acceptable levels of $\mathrm{pH}$ are 6.5 to 8.4 [18]. Thus the water from all the boreholes except borehole 4 during the wet month is suitable for good agricultural produce (Table 2).

The EC for borehole water either exceeded or did not exceed the DWAF [17] recommended guideline of $70 \mathrm{mS} / \mathrm{m}$ for domestic use. The EC values ranged from $1.82 \mathrm{mS} / \mathrm{m}$ to $141.53 \mathrm{mS} / \mathrm{m}$, for all the boreholes for both the wet and dry months (Table 2). The low EC values indicate low salt concentrations, while the high EC values indicate high salt concentrations. It is only in B5 and B6 where EC values exceeded the DWAF [17] recommended guideline for domestic use though they are lower than the maximum allowable DWAF [17] of $150 \mathrm{mS} / \mathrm{m}$.

Calcium concentrations varied from one borehole to the other. Calcium levels in B1 and B2 on top of the mountain farm were between a minimum of $2.0 \mathrm{mg} / \mathrm{L}$ and a maximum of $3.2 \mathrm{mg} / \mathrm{L}$ for both the dry and the wet months and that in B7 at the anklet of the mountain ranged from $4.5 \mathrm{mg} / \mathrm{L}$ to $4.6 \mathrm{mg} / \mathrm{L}$. B3 and B4 on the northern side of the mountain farm and, B5 and B6 on the southern side of the mountain farm had elevated levels of calcium of $3.0 \mathrm{mg} / \mathrm{L}$ to $17.6 \mathrm{mg} / \mathrm{L}$ and $18.5 \mathrm{mg} / \mathrm{L}$ to $86.7 \mathrm{mg} / \mathrm{L}$, respectively (Table 2 ). The levels of calcium in all the boreholes have no health and scaling effects, except for B5 and B6 on the southern side of the mountain farm. The latter boreholes have concentrations of calcium higher than the recommended DWAF [17] guideline of $32 \mathrm{mg} / \mathrm{L}$. These concentrations have no health effect, but may cause scaling of domestic appliances [17]. 
Table 2: Groundwater quality of boreholes in the study area.

\begin{tabular}{|c|c|c|c|c|c|c|c|c|c|c|c|}
\hline $\begin{array}{l}\mathrm{B} \\
\mathrm{H} \\
\mathrm{n} \\
\mathrm{o}\end{array}$ & Date & $\begin{array}{l}\text { Turbi } \\
\text { dity }\end{array}$ & $\mathrm{EC}$ & $\mathrm{pH}$ & $\mathrm{Ca}$ & $\mathrm{Mg}$ & $\mathrm{Zn}$ & $\mathrm{Pb}$ & $\mathrm{NO}_{3}$ & $\mathrm{Cl}$ & $\mathrm{SO}_{4}$ \\
\hline $\begin{array}{l}\text { B } \\
1\end{array}$ & $\begin{array}{l}10 / 08 \\
12 / 08\end{array}$ & $\begin{array}{l}61.00 \\
91.00\end{array}$ & $\begin{array}{l}2.02 \\
2.38\end{array}$ & $\begin{array}{l}7.34 \\
6.28\end{array}$ & $\begin{array}{l}3.10 \\
2.20\end{array}$ & $\begin{array}{l}10.80 \\
9.99\end{array}$ & $\begin{array}{l}0.01 \\
0.01\end{array}$ & $\begin{array}{l}0.04 \\
0.04\end{array}$ & $\begin{array}{l}0.99 \\
0.83\end{array}$ & $\begin{array}{l}4.20 \\
10.43\end{array}$ & $\begin{array}{l}1.29 \\
1.47\end{array}$ \\
\hline $\begin{array}{l}\text { B } \\
2\end{array}$ & $\begin{array}{l}10 / 08 \\
12 / 08\end{array}$ & $\begin{array}{l}2.55 \\
0.55\end{array}$ & $\begin{array}{l}2.52 \\
1.82\end{array}$ & $\begin{array}{l}7.12 \\
6.71\end{array}$ & $\begin{array}{l}2.00 \\
3.20\end{array}$ & $\begin{array}{l}11.70 \\
12.70\end{array}$ & $\begin{array}{l}0.02 \\
0.02\end{array}$ & $\begin{array}{l}0.04 \\
0.04\end{array}$ & $\begin{array}{l}1.52 \\
0.26\end{array}$ & $\begin{array}{l}3.93 \\
4.14\end{array}$ & $\begin{array}{l}1.07 \\
1.16\end{array}$ \\
\hline $\begin{array}{l}\text { B } \\
3\end{array}$ & $\begin{array}{l}10 / 08 \\
12 / 08\end{array}$ & $\begin{array}{l}0.35 \\
0.20\end{array}$ & $\begin{array}{l}14.04 \\
14.94\end{array}$ & $\begin{array}{l}8.00 \\
7.22\end{array}$ & $\begin{array}{l}9.40 \\
3.00\end{array}$ & $\begin{array}{l}78.80 \\
69.80\end{array}$ & $\begin{array}{l}0.01 \\
0.00\end{array}$ & $\begin{array}{l}0.05 \\
0.05\end{array}$ & $\begin{array}{l}43.81 \\
44.75\end{array}$ & $\begin{array}{l}60.89 \\
66.82\end{array}$ & $\begin{array}{l}7.00 \\
10.50\end{array}$ \\
\hline $\begin{array}{l}\text { B } \\
4\end{array}$ & $\begin{array}{l}10 / 08 \\
12 / 08\end{array}$ & $\begin{array}{l}0.25 \\
0.20\end{array}$ & $\begin{array}{l}11.36 \\
16.72\end{array}$ & $\begin{array}{l}8.24 \\
8.94\end{array}$ & $\begin{array}{l}12.70 \\
17.60\end{array}$ & $\begin{array}{l}78.20 \\
75.60\end{array}$ & $\begin{array}{l}0.21 \\
0.49\end{array}$ & $\begin{array}{l}0.06 \\
0.05\end{array}$ & $\begin{array}{l}35.73 \\
20.90\end{array}$ & $\begin{array}{l}80.59 \\
65.49\end{array}$ & $\begin{array}{l}8.98 \\
7.85\end{array}$ \\
\hline B & $10 / 08$ & 9.70 & 141.53 & 8.04 & 18.50 & 115.2 & 0.00 & 0.05 & 37.82 & 195.39 & 26.91 \\
\hline 5 & $12 / 08$ & 4.55 & 114.57 & 7.13 & 86.70 & 111.7 & 0.04 & 0.07 & 24.14 & 257.54 & 25.05 \\
\hline B & $10 / 08$ & 7.77 & 141.17 & 8.03 & 55.10 & 143.9 & 0.00 & 0.06 & 19.39 & 322.24 & 24.58 \\
\hline 6 & $12 / 08$ & 3.45 & 109.97 & 7.15 & 49.90 & 94.70 & 0.02 & 0.06 & 35.02 & 116.10 & 22.35 \\
\hline B & $10 / 08$ & 0.20 & 2.19 & 7.42 & 4.60 & 14.70 & 0.00 & 0.04 & 0.906 & 4.88 & 1.36 \\
\hline 7 & $12 / 08$ & 1.45 & 2.73 & 6.91 & 4.50 & 15.90 & 0.00 & 0.05 & 0.977 & 6.23 & 1.75 \\
\hline
\end{tabular}

Rail [19] indicated that calcium in groundwater may be leached from the soil and other natural sources. B1 and B2 are located in a sedimentary rock classified as arenite (Fig. 1). The concentration of calcium in this rock is likely to be low since it contains no carbonates which are sources of high concentrations of calcium in groundwater as reported by Krešić [16]. The rock type in B3 and B4 is gneiss whereas B5, B6 and B7 are located in basalt. Basalt and gneiss are classified as igneous and metamorphic rocks which according to Krešić [16], naturally have low concentrations of calcium. This shows that the geology of all the sampling sites result in low concentrations of calcium. Thus, the elevated calcium concentrations in groundwater from B3 and B4, and B5 and B6 are due to the farming activities practiced in the farms where they are located. The low calcium concentrations in B1 and B2 also show that the rate of application of fertilizers containing calcium is low in the top of mountain farm where these boreholes are located. This could be due to the fact that the farm mostly uses organic fertilizers from plant residues.

Magnesium levels like those of calcium were low in B1, B2 and B7, and high in B3, B4, B5 and B6. The levels of magnesium in all of the boreholes range from $9.99 \mathrm{mg} / \mathrm{L}$ to $143.9 \mathrm{mg} / \mathrm{L}$ (Table 2) for both the wet and the dry months. From Table 2 it can be seen that the levels of magnesium in groundwater differ 
from borehole to borehole and this difference can be associated with different agricultural activities and/or geochemistry at specific sites. The levels of magnesium in boreholes found on the same site (B1 and B2, B3 and B4, B5 and B6) are mostly comparable with a few deviations that can be attributed to localized variations. The levels of magnesium in all the boreholes is higher during the dry month as compared to the wet month except for B2 and B7; this is expected since groundwater gets diluted from recharge in the wet month, resulting in relatively low concentrations. The high levels of magnesium and calcium result in hard water, which in turn affect the boilers used in the farms and this becomes a problem to the farmers. The variations of magnesium and calcium in the boreholes are influenced by how much magnesium and calcium the agricultural activities and/or geochemistry contribute to groundwater.

Magnesium naturally occurs in volcanic rocks such as basalts [15], metamorphic rocks $[15,16)$ and sedimentary rocks [15], which dominate the study area. This shows that magnesium is naturally available in groundwater from all the sampling sites. The natural concentration of magnesium in groundwater is generally low [16]. Thus, groundwater in all the sampling sites generally has low natural concentrations of magnesium. This shows that the elevated magnesium concentrations in groundwater from B3, B4, B5 and B6 are due to farming activities. Copper, manganese, cadmium, iron, fluoride and phosphate were not detected. The detection limit of IC and AAS is $0.1 \mu \mathrm{g} / \mathrm{L}$. The results of zinc and lead (Table 2) were both in trace quantities and within the DWAF $[17,18]$ recommended levels for domestic and agricultural water uses. This is because these trace metals are found in groundwater in indeterminate quantities or traces which generally do not exceed $1 \mathrm{ppm}$ as shown by Karanth [15]. The low concentrations of these trace metals in groundwater show that the farming activities taking place in the study area do not have any impact on their concentrations in groundwater. Though some of the minerals like copper have been reported to be available in Soutpansberg Mountains they are likely to be localized and found at specific depths.

Although the sampling sites are characterized by metamorphic, igneous and sedimentary rocks, the absence of fluoride in groundwater shows that the fluoride bearing minerals such as fluorspar, rock phosphate, cryolite, apatite, mica, hornblende and fluorite are lacking in the geological formations in the sampling sites. The high calcium concentrations in B5 and B6 may also have contributed to low or no fluorides in groundwater. This is because high concentrations of calcium in groundwater decrease the solubility of fluoride bearing minerals [20]. The findings of Odiyo and Makungo [13] showed that increase in calcium is associated with decrease in fluoride and vice versa. Fluoride concentrations in the Soutpansberg area are localized as neighbourhood areas such as Siloam Village in Nzhelele have been shown by Odiyo and Makungo $[12,13]$ to have high fluoride concentrations.

The non-occurrence of iron in groundwater indicate that microorganisms that assist in its oxidation to divalent iron content are absent in the geologic formations of the study area. Phosphate could not be detected in groundwater because its concentration in groundwater is usually less than a few tenths or 
hundredths of $\mathrm{mg} / \mathrm{L}$ as a result of low solubility of most inorganic phosphorus compounds as reported in Hem [21]. Though phosphate is a constituent of fertilizers, dissolved phosphorus compounds are easily precipitated or adsorbed by clay minerals and metal oxides [16] resulting in low or no phosphate in groundwater.

The chloride concentrations vary from one borehole to another depending on how much chloride is available for leachability to groundwater either from agricultural activities or geochemistry. The chloride levels for boreholes B1, B2, B3, B4 and B7 for both the wet and dry months (Tables 2) fall within the DWAF [17] guideline of $100 \mathrm{mg} / \mathrm{L}$. B3 and B4, had elevated chloride concentrations between $60.89 \mathrm{mg} / \mathrm{L}$ and $80.59 \mathrm{mg} / \mathrm{L}$ (Table 2), which however falls within the recommended DWAF [17] guideline for domestic use. The concentrations of chloride in these boreholes therefore do not pose any significant effect on human health. B5 and B6 have chloride levels during both the wet and dry months (Table 2) that exceed the recommended DWAF [17] guidelines for safe human consumption. Chloride concentrations in the range $100-200 \mathrm{mg} / \mathrm{L}$ have no aesthetic or health effects but they cause possible increase in the corrosion rate in domestic appliances while concentrations in the range $200-600 \mathrm{mg} / \mathrm{L}$ have a distinctly salty taste which does not affect human health but can cause noticeable increase in corrosion rates in domestic appliances [17]. Thus the high chloride concentrations in B5 and B6 can cause corrosion of domestic appliances in the farms.

Karanth [15] indicated that minor sources of chloride in igneous and metamorphic rocks result in low natural concentrations of chloride in groundwater. Metamorphic rocks are characterized by low concentration of chloride [19]. Thus the natural concentration of chloride in groundwater found in igneous and metamorphic rocks is generally low. This explains the low concentration of chloride in B1 and B2. The elevated chloride concentrations in B3, B4, B5 and B6 are due to the farming activities around these sampling sites. The chemicals from agricultural activities and/or geochemistry dissolve in runoff and leach into groundwater aquifers to increase the concentration of chlorides. However, dilution from recharge may also reduce the chloride concentrations during the wet month.

Nitrates were within DWAF [17] acceptable levels of $6 \mathrm{mg} / \mathrm{L}$ for domestic use in $\mathrm{B} 1, \mathrm{~B} 2$ and $\mathrm{B} 7$ with values ranging from a minimum of $0.26 \mathrm{mg} / \mathrm{L}$ to a maximum of $1.52 \mathrm{mg} / \mathrm{L}$ (Table 2). B3, B4, B5 and B6 had nitrate concentrations above the DWAF [17] guidelines for domestic water use; one of the boreholes had a maximum value of $44.75 \mathrm{mg} / \mathrm{L}$ (Table 2). The elevated nitrate concentrations from B3 and B4 may be from decaying plant materials from the farm. The high nitrate concentrations in boreholes B5 and B6 may be from the animal waste, as there are cattle and goats on the site. The waste in sludge form may percolate underground and thus contaminate the groundwater. The high rate of leaching of nitrates from agricultural fertilizers and waste sludge into the groundwater through runoff during rainy seasons or irrigation increases the concentration of nitrates in groundwater. Schilling and Wolter [10] reported that elevated nitrate concentrations in groundwater are common around dairy and 
poultry operations, barnyards, and feedlots. However, the increased volume of water from recharge results in dilution, which may also reduce the nitrate concentration during the wet period, or dry period with excessive irrigation.

The sulphate concentrations in all the boreholes (Table 2) comply with the DWAF [17] recommended guideline of $200 \mathrm{mg} / \mathrm{L}$ for domestic use. The sulphate concentrations though low in each site, vary from one borehole to the other (Table 2) indicating different levels of availability in different borehole sites. Thus the effect of agricultural activities or geochemistry on sulphate availability varies from one site to another. The low sulphate levels indicate the low abundance of sulphur bearing rocks in the Soutpansberg area. The agricultural activities in the study area do not have a significant impact on sulphate concentration in the boreholes.

\section{Conclusion}

The study showed that the groundwater quality within the Soutpansberg varies from one borehole to another and from one farm/site to the other. The concentrations of the chemical parameters are localized. However, the spatial variations could be linked to the differences in the agricultural activities and localized geochemistry effects. The study found that the agricultural activities practiced in farms where B3, B4, B5 and B6 are located resulted in elevated concentrations of calcium, chloride, magnesium and nitrates in groundwater.

Copper, manganese, cadmium, fluoride, iron and phosphate were not detected in all the boreholes in the study area. Zinc and lead concentrations (Table 2) were in trace quantities in groundwater. The absence of fluoride and iron in groundwater showed the absence from geological formations of fluoride bearing minerals and microorganisms that assist in iron oxidation to divalent iron content respectively. Phosphate could not be detected in groundwater because of its natural low concentration in groundwater as a result of low solubility of most inorganic phosphorus and the fact that dissolved phosphorus compounds are easily precipitated or adsorbed by clay minerals and metal oxides. The sulphate concentrations in all the boreholes were within the recommended guideline for agricultural and domestic use due to the low abundance of sulphur bearing rocks in the Soutpansberg area.

The study found that the geologic formations of the study area do not have significant impact on the concentrations of the metals and non-metals in groundwater. In conclusion, the agricultural activities practiced in farms where B3, B4, B5 and B6 are located resulted in elevated levels of calcium, chloride, magnesium and nitrates in groundwater. The management of groundwater pollution requires that monitoring and intervention be done at the farm and borehole level where contamination takes place.

\section{References}

[1] Aghazadeh, N. \& Mogaddam, A. A., The hydrochemical evaluation of groundwater quality in the Harzandat plain aquifer, Northwest of Iran, The 
$1^{\text {st }}$ International Applied Geological Congress, Department of Geology, Islamic Azad University-Mashad Branch, Iran, pp. 464-470, 2010.

[2] Moore, R.B., Quality of water in the fractured-bedrock aquifer of New Hampshire, U.S. Geological Survey Scientific Investigations Report 2004-5093, 30 pp., 2004.

[3] Harter, T., Groundwater quality and groundwater pollution, University of California Publication 8084, reference sheet 11.2, United State of America, 2003.

[4] Abdalla, A.F. \& Scheytt, T., Hydrochemistry of surface water and groundwater from a fractured carbonate aquifer in the Helwan area, Egypt, J. Earth Syst. Sci., 121(1), pp. 109-124, 2012.

[5] Yadav, A., Sonje, A., Mathur, P., Chandra, A., Jain, D.A. and Pardeshi, C., Detailed study of ground water, contamination sources and approaches to clean ground water, International Journal Of Comprehensive Pharmacy, 2(2), pp. 1-5, 2012.

[6] Cho, J.C., Cho, H.B. \& Kim, S.J. Heavy contamination of a subsurface aquifer and a stream by livestock wastewater in a stock farming area, Wonju, Korea, Environmental Pollution, 109, pp. 137-146, 2000.

[7] Ongley, E.D., Control of water pollution from agriculture, FAO drainage paper no. 55, FAO of the United Nations, pp. 4, 1996.

[8] Filintas, A., Dioudis, P., Stamatis, G., Hatzopoulos, J. \& Karyotis, T., Environmental assessment of groundwater nitrate pollution from agricultural wastes and fertilizers in central Greece watersheds using remote sensing and GIS, $3^{\text {rd }}$ International Conference AQUA 2008 on: Water Science and Technology, 2008.

[9] Dioudis, P., Filintas, A. \& Pateras, D., Drip irrigation frequency effects on movement and concentration of nitrates on corn crop, Proceedings of Scientific Congress on the Management of Aquatic Resources and the Sustainable Development of Thessaly, The $3^{\text {rd }}$ Conference of Thessaly Development, Company of Thessalian Studies, (ETHEM), Larissa, pp. 159-171, 2003.

[10] Schilling, K.E. \& Wolter, C.F., Contribution of base flow to nonpoint source pollution loads in an agricultural watershed. Ground Water, 39(1), pp. 49-58, 2001.

[11] Brandl, G., Geology, In: Macdonald, I.A.W., Gaigher, I., Gaigher, R. \& Berger, K. (eds), A first synthesis of the environment, biological and cultural assets of The Soutpansberg-study area, Lajuma Synthesis Workshop, 2003.

[12] Odiyo J.O. \& Makungo R., Fluoride concentrations in groundwater and human health impact in Siloam Village, Limpopo Province, South Africa, Water SA, 38(5), pp. 731-736, 2012.

[13] Odiyo, J.O. \& Makungo, R., Fluoride concentrations in groundwater, human health impact and possible remediation in Siloam Village, Limpopo Province, South Africa, Biennial Groundwater Conference, Somerset West, Cape Town, South Africa, 2009. 
[14] Krasny, J. \& Sharp, J.M., Groundwater in fractured rocks, Taylor and Francis Group Publishers, pp. 20-91, 2007.

[15] Karanth, K.R., Groundwater assessment: development and management, McGrawHill Publishers, New Delhi, 720, 1987.

[16] Krešić, N., Hydrogeology and groundwater modelling, $2^{\text {nd }}$ Edition, CRC Press Publishers, New York, London, pp. 368-377, 2007.

[17] DWAF, South African water quality guidelines, vol. 1: Domestic water use, $2^{\text {nd }}$ Edition, Pretoria, 1996a.

[18] DWAF, South African water quality guidelines, vol. 7: Aquatic ecosystems, $2^{\text {nd }}$ Edition, Pretoria, $1996 \mathrm{~b}$.

[19] Rail, C.D., Groundwater contamination: contamination, sources and hydrology, vol. 1, CRC Press Publishers, New York, London, pp. 18-22, 2000.

[20] Murray, J.J., Appropriate use of fluorides for human health, World Health Organization, Geneva, 1986.

[21] Hem, J.D., Study and interpretation of the chemical characteristics of natural water, $3^{\text {rd }}$ Edition, USGS Water Supply Paper 2245, 1985. 